\title{
Phytochemical aspects and biological activities of essential oil of species of the family Canellaceae: A review
}

\author{
Júlia Assunção de Castro Oliveira ${ }^{1}$, Rafaela Karin de Lima $^{2}$, Érica Alves Marques ${ }^{1} \&$ Manuel Losada \\ Gavilanes $^{3^{*}}$ \\ ${ }^{1}$ Department of Agriculture, Post-graduate Program in Medicinal, Aromatic and Spicy Plants, Federal University of Lavras, Lavras, Minas \\ Gerais, Brazil \\ ${ }^{2}$ Department of Natural Sciences, Laborary of Organic Chemistry, Federal University of São João del Rei, São João del Rei, Minas Gerais, \\ Brazil \\ ${ }^{3}$ Department of Biology, Federal University de Lavras, Lavras, Minas Gerais, Brazil
}

\section{Article history}

Received: 05 June 2019

Accepted: 09 July 2019

Published: 18 July 2019

\section{Publisher}

Horizon e-Publishing Group

\section{*Correspondence}

Manuel Losada Gavilanes

凶mlgavilanes@ufla.br

\begin{abstract}
Survey have proven the popular Canellaceae family use to treat various diseases such as: muscular pains, infections, stomatitis, anti-malaric, healing, among others. The main use of these species is in the extracts form and essential oils extracted from the leaves and stem. Highlighting the importance of this family on the pharmacological point of view and the fact that few studies in the literature have reported the characterization of the essential oils compounds and their respective biological activities. The objective of this study was to carry out a systematic review of previous studies on essential oils of the Canellaceae family species and their biological activities. The databases Scopus, Web of Science and PubMed were used for the search and a bibliographical manager was used. A total of 143 files were analyzed, of which 21 presented the phytochemical analysis and / or essential oils biological activities of these species. Few species have been studied so far, such as Canella winterana, Cinnamosma fragans, Cinnamosma madagascariensis, Cinnamodendron dinisii. It can be observed that the major constituents for these species essential oils were: 1,8-cineol, linalool, limonene, alpha and beta-pinene. And that the main proven activities were: antibiotic, antifungal, insecticide, larvicide, trypanocidal, cytotoxic, molluscicide, immunomodulatory, anti-inflammatory and anticonvulcionate. From this literature review, it was possible to identify species that have not yet started studies and possible activities of their essential oils, mainly due to the almost homogeneous presence of the major constituents, making possible new research as well as projects and programs.
\end{abstract}

Keywords: anti-inflammatory; antimicrobial; cytotoxic; drimane sesquiterpenes

Citation: Oliveira JAC, Lima RK, Marques EA, Gavilanes ML. Phytochemical aspects and biological activities of essential oil of species of the family Canellaceae: A review. Plant Science Today 2019; 6(3):315-320. https://doi.org/10.14719/pst.2019.6.3.585

Copyright: (C) Oliveira et al (2019). This is an open-access article distributed under the terms of the Creative Commons Attribution License, which permits unrestricted use, distribution, and reproduction in any medium, provided the original author and source are credited (https://creativecommons.org/licenses/by/4.0/).

Indexing: Plant Science Today is covered by Scopus,Web of Science, BIOSIS Previews, ESCI, CAS, AGRIS, CABI, Google Scholar, etc. Full list at http://www.plantsciencetoday.online

\section{Introduction}

Essential oils are chemically complex products originated through the secondary metabolism of plants and responsible for activities that increase the plants resistance to the environment. They can be extracted from various aromatic plants and are 
usually present in all plant organs, varying their content and composition according to some factors such as: the organ, collection time and place, species, among others. In general, they are liquid, volatile, soluble in organic solvents, less dense than water and colorless (1-4). Biological or pharmacological activity is an expression used to describe the beneficial or deleterious effects of a chemical compound or a compounds class on the various organisms (bacteria, fungi, animals, plants) (2).

The Canellaceae Mart. family has 5 generas: Canella P. Bowne, Cinnamodendron Endl., Cinnamosma Baill., Pleodendron Tiegh, Warburgia Engl. and 21 currently accepted species (5); they are trees and rarely shrubs, aromatic and most often with the cinnamon smell (6). They are native of Tropical America, Africa and Madagascar and characterized by the presence of secretory structures in their leaves and wood $(6,7)$.

Only the Cinnamodendron genus occurs in Brazil, with four species: C.axillare (Ness) Endl. ex Walp., C. sampaioanum Occhioni, C. dinisii Schwacke and C. occhionianum F.Barros \& J.Salazar. These species can be found in the Amazon Forest, Atlantic Forest from the state of Minas Gerais to Rio Grande do Sul $(6,7)$. Representatives of this genera were also found on the Cardose island located in the city of Cananéia and on the Pereque River cliffs State of São Paulo (8).

The Canellaceae family has been studied since 1756 when P. Browne created the Canella genre (6). Since then publications with discoveries of other genera and species have been published, contributing even more to the knowledge of this family. There are reports on the chemical composition of extracts and essential oils extracted from the leaves and stem as the evidence of various pharmacological activities related to the presence of certain classes of compounds, others with isolated compounds and also the evaluation of the synergism between them (9-12). These studies confirm the traditional use of communities throughout the world that use this family plant parts for the treatment of muscular pain, wound healing and also have antibiotic, antifungal, pertussis, stomatitis, vermifuge, diuretic, antisyphilis, antimalarial, inseticidal and citotoxic properties (9-17).

The genera Cinnamodendron with botanical synonym Capsicodendron Hoehne, in addition to the Brazilian species mentioned above, has another 6 species: $C$. angustifolium Sleumer, $C$. corticosum Miers., C. cubense Urb., C ekmanii Sleumer, $C$. tenuifolium Uittien and $C$. venezuelense Steyerm native of Tropical America (5) and like other family genera, have also been used by traditional communities to cure several diseases. However, only the $C$. dinisii had their studies started from a phytochemical point of view and until some biological activities (molluscicide, antimicrobial, antioxidant, insecticide) were confirmed for the essential oils and extracts extracted from this tree leaves and barks $(4,17-$ 22).

Previously, during the beginning of this systematization, similarities were observed between the biological activities, the chemical composition of the essential oils of this family species and the traditional use by the communities around the world.

Due to the volume of this family studies on chemical composition and biological activities of the essential oils presented to date (143 documents) it is relevant to systematize for an understanding and identification of future research works and / or research programs.

Due to the lack of information on the chemical composition and biological activities of the essential oils of the Canellaceae family occurring in Brazil, the present work had as objective to make a survey of which species of this family had studies on the chemical composition and also the biological activities of the essential oils.

\section{Methodology}

A systematic review was carried out through a bibliographical survey on essential oil and biological activities of the species of the botanical family Canellaceae.

The searches were carried out at the bases: Scopus, Web of Sciense and Pub Med from 1961 to May 2018. The following search strategy was used in each of the databases. The following ones were used as key words: 'Canellaceae', 'Canella', 'Cinnamosma', 'Cinnamodendron', 'Capsicodendron', 'Warburgia' combined with 'Essential Oil'. In addition, as a second search strategy we selected for this survey books, complete texts of dissertations and other sites to complement some data.

The reference manager EndNot X7 was used. As inclusion criteria, it was established that all the archives available in these databases containing essential oil characterization surveys and / or pharmacological activities in vivo or in vitro would be analyzed. As exclusion criterion, it was established that the chemical composition and pharmacological activity of any other classes would not be addressed in the present study.

\section{Results}

A total of 143 files were analyzed, including scientific articles, communications, theses, dissertations and books. The PubMed and Web of Science databases, share some works with the Scopus base, however some can only be found in 
the first two bases, especially those related to biological activities.

From this search, it was possible to see that the genera with the greatest number of works is the Warburgia with occurrence in the African continent, while the genera Cinnamodendron of occurrence in the Brazilian territory was the one with smaller number. It was also noticed that in general the Canellaceae family has few realized works that date from 1961 until the present day.

Of the 143 analyzed works, 21 were chosen because they comprised on the theme: phytochemistry of the essential oils of the Canellaceae family. In these works, four species had been explored phytochemical and pharmacological activities: Canella winterana (L.) Gaertn., Cinnamosma fragrans Baill., Cinnamosma madagascariensis Danguy., Cinnamodendron dinisii Schwacke.

Most of the works (38.09\%) followed the extraction of essential oils by hydrodistillation method and the most used part was leaves (85.71\%). Some studies (19.04\%) did not extract the essential oil and opted for the use of commercial oils.

It was possible to realise that the compounds amount and their percentage change due to species, collection site, seasonality, type and time of extraction and organ used. However, the major chemical constituents for most species were: 1,8-cineole, linalool, limonene, alpha and betapinene, and driannic sesquiterpenes.

For the Warburgia genres, no studies were found on the essential oil chemical composition and its biological activities. In the works performed with the Warburgia salutares (Bertol. f) Chiov., $W$. ugandensis Sprague, $W$. stuhlmannii Engl., several extracts were used and the chemical compounds that were isolated form mainly drimic sesquiterpenes. These isolated extracts or compounds have demonstrated antihelmintic activities (12), trypanocidal (10), antimalarial (23), immunostimulatory (11), antimicrobial (24), molluscicide (25) among others.

\section{Discussion}

The Canellaceae family has five genera and 21 species, of which only 9 were studied regarding the chemical composition and biological activities up to the moment of this survey. The genera Canella, Cinnamosma and Cinnamodendron are the ones that have more work on the chemical composition and biological activities of the essential oils, however, when compared to the genera of other plant families, this number is still small.

The family chemotaxonomic marker are the drimane sesquiterpenes (26, 27). Chemotaxonomic markers are molecules present in secondary or primary metabolites that allow the differentiation of specimens at any hierarchical level and provide characteristics of a group of plants (family, genera). In addition, these markers can be used to label the metabolic rate of a vegetable group $(28,29)$.

The drimane sesquiterpenes are a class of saturated hydrocarbons that derive from sesquiterpene alcohol drimenol and present bactericidal, antifungal activities, plant growth modulator, cytotoxic, phytotoxic and pesticidal effect (30). In addition, they are also discouraging of the feeding of insects, anticancer, antibiotics and molluscicides (18).

\section{Warburgia}

Species of this genus have been used by traditional communities as: expectorant, antibiotic, antifungal, antirheumatic, anti-malarial and for gastrointestinal problems and skin disorders (31). The results showed that no scientific studies on the chemical composition and biological activities of the species of this genera were found.

\section{Canella}

Canella is a genera with only 1 species Canella winterana. The content of this essential oil extracted by steam distillation and hydrodistillation of leaves and stem, ranged from $0.42-0.65 \%$ and its major constituents: 1,8-cineol (3.76 - 37\%), linalool (2 - 8.5\%), caryophylene oxide (37.4\%), (E)-caryophyllene (18.8\%) and myrcene (9.1 - 68\%) (14, 32-35). The biological activity demonstrated until this moment for this species is antibacterial for the bacteria of the Mycobacterium Lehmann \& Neumann ( $M$. tuberculosis Zopf, $M$. avium Chester 1901 emend. Thorel et al. and $M$. kansasii Hauduroy) genera that causes tuberculosis (14).

\section{Cinnamosma}

Cinnamosma is a genera with 3 species $C$. fragrans, C. macrocarpa and C. madagascariensis. $C$. frangrans is indicated in the Madagascar pharmacopoeia for the treatment of pertussis, stomatitis, verminoses, liver diseases, diuretic and anti-syphilis (13). The studies do not contemplate the information on the content of this essential oil. The essential oils were obtained from the steam distillation or hydrodistillation of the leaves and stems, where the major constituents were: 1,8 cineole ( $45-57.5 \%)$, alpha-pinene (3.5 - 7\%), betapinene $(5-11.8 \%)$, linalool $(2-95.8 \%)$ and sabinene (10.6\%) (36-42). Among the biological activities proven for this species are: antibacterial (37-39), antiviral (38), anti-inflammatory, analgesic, healing, immunoregulatory and antipruritic (42).

The $C$. madascariensis is indicated by Madagascar pharmacopoeia for the treatment of coughs and dysentery (13). The content of this essential oil extracted by steam distillation of 
leaves and stems have a content between 0.42$0.65 \%$ and its major constituents: linalool (6.6 $30.1 \%)$, limonene $(12-17.8 \%)$, alpha-pinene $(8.4-$ $19.5 \%)$, beta-pinene $(7.1-49.9 \%)$, myrcene $(17.9 \%)$ and beta-phellandren (15.3\%) (43-45). Its proven biological activities were anticonvulsant, sedative (45) and lavicide for Culex quinquefasciatus Say (44).

For the Cinnamosma macrocarpa no works were found on the essential oil chemical composition and biological activities.

\section{Cinnamodendron}

This is a genera of Brazilian occurrence with four species: $C$. axillare, $C$. dinisii, $C$. occhionianum and C. sampaioanum (6-8) and 6 other species: $C$. angustifolium Sleumer, $C$. corticosum Miers., $C$. cubense Urb., $C$ ekmanii Sleumer, $C$. tenuifolium Uittien and $C$. venezuelense Steyerm natives of Tropical America. It was observed that the only species in which studies conducted on essential oil chemical composition and biological activities was the $C$. dinisii, which is traditionally used to treat the various diseases ("panacéia") (7). The studies performed and obtained the essential oil through hydrodistillation. The content of this oil extracted from stem has $0.17 \pm 0.08 \%)(19)$ and oil extracted leaves varied between $(0.16-2.03 \%)(4,20,21)$. The main constituents of leaf essential oil are: limonene (68.5\%), bicyclogermacrene (7.56 $30.8 \%$ ), and espatulenol (13.5\%), in addition to the presence of the drimane sesquiterpenes drimenol $(0.2-2.05 \%)(4,20-22,46-48)$. For this essential oil, the following biological activities have been proven: antibacterial $(4,47)$, antifungal $(4,47)$ antioxidant $(4,20)$, cytotoxic $(22,49)$, leishmanicide (22), and insecticide (46).

It has been observed that species no works were recorded on the essential oil chemical composition and biological activities for the species such as $C$. axillare, $C$. occhionianum, $C$. sampaioanum, $C$. angustifolium, $C$. corticosum, $C$. cubense, $C$. ekmanii, $C$. tenuifolium and $C$. venezuelense.

\section{Conclusion}

The Canellaceae family has numerous species that are widely used by traditional communities around the world. The essential oils of the species of this family have a complex mixture of monoterpenes and sesquiterpenes. It was possible to observe the similarity between the chemical constituents in different species analyzed and there is also difference in the quantity and the percentage of these compounds depending up on the species, extractive method and time duration of extraction, seasonality, collection site and biological activities of the used part. The essential oils that have been proven by studies are antibacterial, antifungal, anti-inflammatory, antipruritic, analgesic, antioxidant ( $\beta$-carotene), anti-infectious, anticonvulatory, antimalarial, healing, cytotoxic, insecticide, larvicide, leishmanicide, sedative, trypanocidal and health promoter, which proves the traditional use of these oils and demonstrates the pharmacological importance of this family.

In general, few species of this family have been studied for the chemical composition, pharmacological activities and essential oil content. For Warburgia, Pleodendron and Cinnamodendron genera (except Cinnamodendron dinisii) and Cinnamosma macrocarpa, no references were found on the subject mentioned. It is believed that more studies on the species of this family should be formulated, mainly due to the already proven biological activities. It is suggested that the studies be performed also for roots, flowers, seeds and fruits aiming to unravel the information on the essential oils of the species of the family Canellaceae.

\section{Acknowledgements}

We thank the Federal University of Lavras (UFLA) for the space provided for this review.

\section{Authors' contributions}

All authors contributed to the content of the manuscript and approved the final version.

\section{Competing Interest}

The authors declare that they have no competing interest.

\section{References}

1. EN ISO 9235. ICS 71.100.60; 01.040.71. English Version. Aromatic natural raw materials- Vocabulary (ISO 9235:2013). 2013. Available in: https://www.iso.org/obp/ ui\#!!iso:std:51017:en

2. Simões, CMO, Spitzer, V. Óleos voláteis. In: SIMÕES, CMO et al. 2007. Farmacognosia: da planta ao medicamento. 6. ed. Porto Alegre: UFRGS; Florianópolis: UFSC, p. 1102.

3. Guimarães, LGL, Cardoso, MG, Zacaroni, LM, Lima, RK, Pimentel, FA, Morais, AR. Influência da luz e da temperatura sobre a oxidação do óleo essencial de capim-limão (Cymbopogon citratus (D.C.) Stapf). Quím. Nova. 2008. São Paulo, v. 31, n. 6, p. 1476-1480. http:// dx.doi.org/10.1590/S0100-40422008000600037.

4. Loura, LG, Castro, AP, Solano, AGR, Pacheco, FV, Bertolucci, SKV. Variação sazonal, horário de colheita, composição química e potencial antimicrobiano do óleo essencial de Cinnamodendron dinisii Schwacke. Rev. Bras. Pl. Med. 2016; 18(3): 765-772. https://doi.org/10.1590/1983-084X/0169

5. The Plant List [homepage na Internet]. Família Canellaceae. Citado em: 5 de maio de 2018. Available in: http://www.theplantlist.org/1.1/browse/A/Canellaceae/ 
6. Occhioni, P. Contribuição ao estudo da família "Canellaceae". In: Milanez, FR, Occhioni, P, Paes, EDD’Avila, Labouriau, LFG. Arq. Jard. Bot. R. de Janeiro, 1948; 8: 3-165.

7. Souza, VC, Lorenzi, H. Botânica Sistemática: guia ilustrado para identificação das famílias de Fanerógamas nativas e exóticas no Brasil, baseado em APG III. $3^{a}$ ed. Instituto Plantarum, Nova Odessa, São Paulo, 2012, 768p.

8. De Barros, F, Salazar, J. Cinnamodendron occhionianum, a new species of Canellaceae from Brazil. Novon 2009; 19(1): 11-14. https://doi.org/10.3417/2007040

9. Olila, D, Olwa-Odyek, Opuda-Asibo, J. Antibacterial and antifungal activities of extracts of Zanthoxylum chalybeum and Warburgia ugandensis, Ugandan medicinal plants. African Health Sciences 2001; 1(2).

10. Nibret, E, Ashour, ML, Rubanza, CD, Wink, M. Screening of some Tanzanian medicinal plants for their trypanocidal and cytotoxic activities. Phytotherapy Research 2010; 24(6): 945-947. https://doi.org/10.1002/ptr.3066

11. Ngure, P, Ng'ang'a, Z, Kimutai, A, Kepha, S, Mong'are, S, Ingonga, et al. Immunostimulatory responses to crude extracts of Warburgia ugandensis (Sprague) subsp ugandensis (Canellaceae) by BALB/c mice infected with Leishmania major. Pan Afr Med J, 2014; 17 Suppl 1: 15. https://doi.org/10.11694/pamj.supp.2014.17.1.3638

12. Nsahlai, IV. In Vitro Evaluation of Anthelmintic Efficacy of Some Plant Species Possessing Proteinases and/or Other Nitrogenous Compounds in Small Ruminants. Alternative, Complementary \& Integrative Medicine 2017; 3:038. https://doi.org/10.24966/ACIM-7562/100038

13. Pernet, R., Meyer, G. Pharmacopée de Madagascar. L'Institut de Recherche Scientifique TananariveTsimbazaza. 1957.

14. Rastogi, N., Abaul, J, Goh,KS, Devallois, A, Philogène, E, Bourgeois P.(1998). Antimycobacterial activity of chemically defined natural substances from the Caribbean flora in Guadeloupe. FEMS Immunology and Medical Microbiology 1998; 20(4): 267-273.

15. Randrianarivelojosia, M, Rasidimanana, VT, Rabarison, H, Cheplogoi, PK, Ratsimbason, M., Mulholland, DA, et al. Plants traditionally prescribed to treat tazo (malaria) in the eastern region of Madagascar. Malaria Journal 2003; 2 : 1-9.

16. Opiyo, SA, Manguro, LOA, Okoth, DA, Ochung, AA, Ochieng, CO. Biopesticidal extractives and compounds from Warburgia ugandensis against maize weevil (Sitophilus zeamais). Natural Products Journal 2015; 5(4): 236-243.

17. Mahmoud, II, Kinghorn, AD, Cordell, GA, Farnsworth, NR. Cytotoxic drimane sesquiterpenoids from Capsicodendron dinisii. Journal of Natural Products 1979; $\quad 42(6)$ : https://pubs.acs.org/doi/pdf/10.1021/np50009a008

18. Bastos, J. K., Gottlieb, OR, Kaplan, MAC, Dos Santos Filho, D, Sarti, SJ Rodrigues, CPS. The molluscicidal properties of cinnamodial isolated from Capsicodendron dinisii. Revista de Ciências Farmacêuticas, 1991; 13: 83-89.

19. Torres, E, Wisniewski Jr, A. Composição química dos componentes voláteis de Capsicodendron dinisii Schwancke (Canellaceae). Quim. Nova, 2010; 33(1): 130132.

20. Andrade, MA, Cardoso, MG, De Andrade, J, Silva, LF, M. L. Teixeira, ML, Resende, JMV et al. Chemical composition and antioxidant activity of essential oils from Cinnamodendron dinisii Schwacke and Siparuna guianensis Aublet. Antioxidants 2013; 2(4): 384-397. https://doi.org/10.3390/antiox2040384

21. Mesquita, J, Salgueiro, L, Cavaleiro, C. Composition of the essential oil from leaves of Capsicodendron dinisii Schwancke from Brazil. Boletin Latinoamericano y del Caribe de Plantas Medicinales y Aromaticas 2013; 12(6): 618-621.

22. Andrade, MA, Azevedo, CS, Motta, FN, Santos, ML, Silva, CL, Santana, JM et al. Essential oils: In vitro activity against Leishmania amazonensis, cytotoxicity and chemical composition. BMC Complementary and Alternative Medicine 2016; 16(1). https://doi.org/10.1186/ $\underline{\text { s12906-016-1401-9 }}$

23. Muthaura, CN, Rukunga, GM, Chhabra, SC, Omar, AS, Guantai, A. N, Gathirwa, J. W et al. Antimalarial activity of some plants traditionally used in treatment of malaria in Kwale district of Kenya. J. Ethnopharmacol. 2007; 112(3): 545-51.

24. Drage, S, Mitter, B, Tröls, C, Muchugi, A, Jamnadass, RH, Sessitsch, A et al. Antimicrobial drimane sesquiter penes and their effect on endophyte communities in the medical tree Warburgia ugandensis. Frontiers in Microbiology 2014; 5 . https://doi.org/10.3389/fmicb.2014.00013

25. Clark, TE, Appleton, CC. The molluscicidal activity of Apodytes dimidiata E. Meyerex Arn (Icacinaceae), Gardenia thunbergia L.f. (Rubiaceae) and Warburgia salutaris (Bertol. F.) Chiov. (Cannelaceae), three South African plants. Journal of Ethnopharmacology 1997; 56: 15-30.

26. Bastos, JK, Kaplan, MAC, Gottliebc, OR. Drimane-Type Sesquiterpenoids as Chemosystematic Markers of Canellaceae. J. Braz. Chem. Soc.1999; 10(2): 136-139.

27. Harinantenaina, L., Takaoka, S. Cinnafragrins A-C, Dimeric and Trimeric Drimane Sesquiterpenoids from Cinnamosma fragrans, and Structure Revision of Capsicodendrin. J. Nat. Prod. 2006, 69.DOI: $10.1021 / \mathrm{np} 0601298$

28. Brant, AJC. Flavonoides, Cumarinas e Benzofuranos como marcadores quimiotaxônomicos em Asteraceae. Dissertação de Mestrado. Instituto de Química, USP, São Paulo, 2003, 182p.

29. Gobbo-Neto, L, Lopes, NP. Plantas Medicinais: Fator de influência no conteúdo de metabolitos secundários. Quimica Nova, 2007; vol.30, p374-381.

30. Jansen, BJM, de Groot, Ae. Occurrence, biological activity and synthesis of drimane sesquiterpenoids. Natural Product Reports 2004; 21, 449.

31. Leonard, CM, Viljoen, AM. Warburgia: A comprehensive review of the botany, traditional uses and phytochemistry. Journal of Ethnopharmacology 2015; 165: 260-285.

32. Adams, RP, Zanoni, TA. Essential oils of plants from hispaniola: 3. the leaf oil of Canella winterana (Canellaceae). Journal of Essential Oil Research 1990; 2(4): 163-165.

33. Abaul, J, Udino, L, Bourgeois, P, Bessière, JM. Composition of the essential oils of Canella winterana (L.) Gaertn. Journal of Essential Oil Research 1995; 7(6): 681-683. http://dx.doi.org/10.1080/10412905.1995.9700530

34. Pino, JA, Rosado, A, Fuentes, V. Leaf oil of Canella winterana (L.) gaertn. From Cuba. Journal of Essential Oil Research 1998; 10(3): 311-312. http://dx.doi.org/10.1080/10412905.1998.9700906 
35. Setzer, WN. Chemical Composition of the Leaf Essential Oil of Canella winterana from Abaco Island, Bahamas. Journal of Essential Oil-Bearing Plants 2007; 10(6): 475479. http://dx.doi.org/10.1080/0972060X.2007.10643581

36. Arnal-Schnebelen, B, Behra, O, Rakotoarison, C, Escoubas, J, Danthu, P. Applications in gynecology of the essential oil of Cinnamosma fragrans Baillon (marketed under the name of Saro). Phytotherapie 2007; 5(2): 7375. https://doi.org/10.1007/s10298-007-0214-x

37. De Billerbeck, VG. Essential oils and antibiotic-resistant bacteria. Phytotherapie 2007; 5(5): 249-253. https://doi.org/10.1007/s10298-007-0265-z

38. Behra, O, Danthu, P, Sarter, S, Radaniela, R, Fourcade, C, Randrianarivelo, $\mathrm{R}$ et al., Saro (Cinnamosma fragrans Baillon) essential oil: Application in health and medicine. ACS Symposium Series, American Chemical Society 2009; 1021: 485-494.

39. Randrianarivelo, R, Sarter S, Odoux, E, Brat, P, Lebrun, $\mathrm{M}$, Romestand, B et al. Composition and antimicrobial activity of essential oils of Cinnamosma fragrans. Food Chemistry 2009; 114(2): 680-684. http://dxdoi.org/10.1016/j.foodchem.2008.10.007

40. Randrianarivelo, R, Danthu, P, Benoit, C, Ruez, P, Raherimandimby, M, Sarter, S. Novel alternative to antibiotics in shrimp hatchery: Effects of the essential oil of Cinnamosma fragrans on survival and bacterial concentration of Penaeus monodon larvae. Journal of Applied Microbiology 2010; 109(2): 642-650. http://dxdoi.org/10.1111/j.1365-2672.2010.04694.x

41. Tucker, AO, Maciarello, MJ, Brown, R, Griffenth, M. A commercial essential oil of mandravasarotra (Cinnamosma fragrans Baillon, Canellaceae) fron Madagascar. Journal of Essential Oil Research, 2008; 20(3):259-260.

http://dxdoi.org/10.1080/10412905.2008.9700006

42. Pidoux, M., Harilalarisoa, H, Iharilanto, R, Rabenoavy, M, Rakotondramanana, R, Ravaoarinirina, $S$ et al. Prevention of postoperative superfi cial infections and healing of lesions with a mixture of oils of Saro and Calophyllum inophyllum: Case of circumcision in Madagascar. Phytotherapie 2012; 10(2): 143-147. http://dxdoi.org/10.1007/s10298-012-0700-7

43. Garcia, G, Rabehaja, D, Charmillon, JM, Ramanoelina, P, Casanova, J, Tomi, F. Integrated analysis of the bark oil from Cinnamosma madagascariensis by GC (RI), GC-MS and NMR. 13C NMR data of cyclocopacamphene and cyclosativene. Natural Product Communications 2017; 12(2): 277-280.

44. Pavela, R, Maggi, F, Ngahang Kamte, SL, Rakotosaona, R, Rasoanaivo, P, Nicoletti, $\mathrm{M}$ et al. Chemical composition of Cinnamosma madagascariensis (Canellaceae) essential oil and its larvicidal potential against the filariasis vector Culex quinquefasciatus Say. South African Journal of Botany 2017; 108: 359-363.

45. Rakotosaona, R, Randrianarivo, E, Rasoanaivo, $\mathrm{P}$, Nicoletti, M, Benelli, G, Maggi, F. Effect of the Leaf Essential Oil from Cinnamosma madagascariensis Danguy on Pentylenetetrazol-induced Seizure in Rats. Chemistry and Biodiversity 2017; 14(10).

46. Do Amaral, W, Deschamps, C, Bizzo, HR, Pinto, MAS, Biasi, LA, Da Silva, LE. Essential oil yield and composition of native tree species from Atlantic forest, South of Brazil. Journal of Essential Oil-Bearing Plants 2017; 20(6): 1525-1535. https://doi.org/10.1080/0972060X.2017.1346484

47. Andrade, MA, Cardoso, MG, Gomes, MS, Azeredo, CMO, Batista, LR, Soares, MJ, et al. Biological activity of the essential oils from Cinnamodendron dinisii and Siparuna guianensis. Brazilian Journal of Microbiology 2015 46(1): $\quad 189-194 . \quad$ http://dx.doi.org/10.1590/S1517$\underline{838246120130683}$

48. Vedovatto, F, Valério Júnior, C, Astolfi, V, Mielniczki, PAA, Roman, SS, Paroul, $\mathrm{N}$ et al. Essential oil of Cinnamodendron dinisii Schwanke for the control of Sitophilus zeamais Motschulsky (Coleoptera: Curculionidae). Revista Brasileira de Plantas Medicinais 2015; 17(4): 1055-1060. http://dxdoi.org/10.1590/1983$\underline{084 \mathrm{X} / 14143}$

49. Andrade, MA, Cardoso MG, Preté, PSC, Soares, MJ, de Azeredo, CMO, Trento, MVC et al. Toxicological Aspects of the Essential Oil from Cinnamodendron dinisii. Chemistry and Biodiversity, 2018. 15(5). https://doi.org/ $10.1002 / \mathrm{cbdv} .201800066 \mathrm{EN}$ ISO 9235. 2013. ICS 71.100.60; 01.040.71. English Version. Aromatic natural raw materials - Vocabulary (ISO 9235:2013). Available in: https://www.iso.org/obp/ui\#!iso:std:51017:en 